\title{
Sistem Informasi Layanan Pengaduan Masalah Pegawai Berbasis Android

\author{
Noviändi ${ }^{1}$, Taufan Syahrudin ${ }^{2}$ \\ 1,2Universitas Esa Unggul, Jakarta, Indonesia \\ noviandi@esaunggul.ac.id, taufansyahrudin9@gmail.com
}

\begin{abstract}
Services provided by an organizational unit or people who work in that organization and employees in other units are known as internal services. The use of web applications for problem complaints services at the Secretariat General of DPD RI is still considered less flexible because the activities of employees and officials within the Secretariat General of DPD RI are mobile and rarely in the room. This research aims to design a mobile-based problem complaint information system by applying the waterfall system development methodology. System requirements analysis was conducted by interviewing two informants with more than two years of service and observing the current system. The study results stated that the problem complaint information system managed to display the things that were expected from the entire menu after being tested using the black-box method. After testing, it is hoped that a mobile-based problem complaint information system can be developed by adding features that support and measure the performance of employees or officials.
\end{abstract}

Keywords: Complaints of Problems, Waterfall, Black-Box Testing

\begin{abstract}
Abstrak
Pelayanan yang diberikan oleh sebuah unit organisasi atau orang yang bekerja pada unit organisasi tersebut dan pegawai dalam unit lain di satu organisasi dikenal dengan pelayanan internal. Penggunaan aplikasi web untuk pelayanan pengaduan masalah di Sekretariat Jenderal DPD RI masih di nilai kurang fleksibel, karena aktivitas pegawai maupun pejabat di lingkungan Sekretariat Jenderal DPD RI bersifat mobile dan jarang berada di ruangan. Tujuan dari penelitian ini adalah merancang sistem informasi pengaduan masalah berbasis mobile dengan menerapkan metodologi pengembangan sistem waterfall. Analisis kebutuhan sistem dilakukan dengan metode wawancara terhadap dua informan dengan lama masa kerja lebih dari dua tahun dan melakukan observasi terhadap sistem yang sedang berjalan. Hasil penelitian menyatakan bahwa sistem informasi pengaduan masalah berhasil menampilkan hal-hal yang di harapkan dari seluruh menu setelah di uji dengan menggunakan metode black-box. Setelah dilakukan pengujian, diharapkan sistem informasi pengaduan masalah berbasis mobile dapat dikembangkan dengan menambahkan fitur-fitur yang mendukung dan mengukur kinerja pegawai ataupun pejabat.
\end{abstract}

Kata kunci: Pengaduan Masalah, Waterfall, Black-Box Testing

\section{PENDAHULUAN}

Pemerintah memberikan pelayanan untuk masyarakatnya yang diatur dalam UU No. 25 tahun 2009 tentang Pelayanan Publik [1]. Adapun Pelayanan internal sebagai layanan yang diberikan oleh sebuah unit organisasi atau orang yang bekerja pada unit organisasi tersebut ke unit-unit lain atau kepada pegawai di dalam unit lain di dalam sebuah organisasi [2]. Salah satu pelayanan internal yaitu pelayanan pengaduan masalah antar pegawai yang terjadi dalam sebuah organisasi atau instansi yang dimana ada sebuah bagian di dalam instansi yang menerima pengaduan masalah dan memperbaiki masalah tersebut. Penelitian terkait perancangan sistem informasi pengaduan masalah sudah banyak dilakukan. Nofyat dkk merancang sistem informasi pengaduan pelanggaran air 


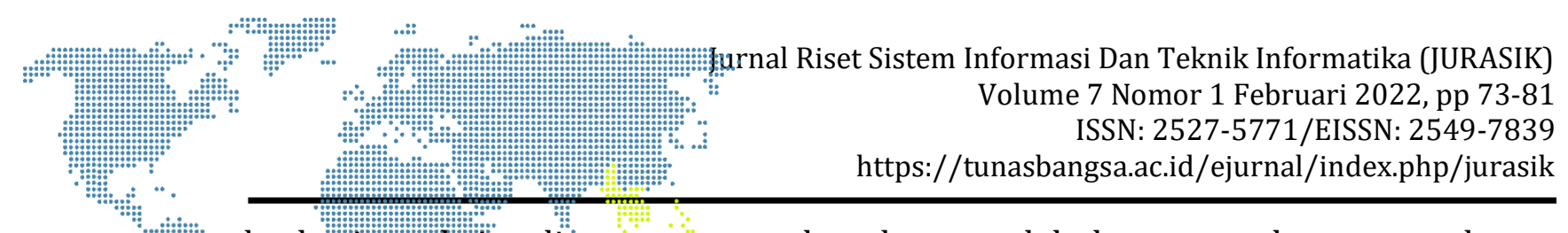

berbásís website dimana masyarakat dapat melakukan pengaduan tanpa harus datang kê kantor PDAM [3].: Sélain itu ada juga penelitian Resli yang membuat sistem informasi pusat pelayanản pengaduan masyarakat (P3M) dan sistem memberikan kemudahan dalam melaporkan data pengaduan masyarakat kepada kepala dinas komunikasi, informatika, statistic dan persandian Kabupaten Kuantan Singigi[4]. Penelitian lain yang dilakukan oleh Firmansyah dkk merancang sistem informasi pengaduan warga berbasis website dan aplikasi tersebut dapat menangani pengaduan yang tepat sasaran[5]. Namun, sistem informasi berbasis website masih kurang fleksibel, karena beberapa website kurang responsive. Sedangkan dengan menggunakan aplikasi mobile jauh lebih fleksibel, responsive, dan aplikasi mobile sangat cocok dengan sistem kerja yang mobile.

Sekretariat Jendral Dewan Perwakilan Daerah Republik Indonesia adalah suatu instansi Pemerintahan yang bertugas untuk melakukan penyelenggaraan administrasi dan keahlian dalam melancarkan pelaksanaan tugas dan wewenang dari Dewan Perwakilan Daerah Republik Indonesia (DPD RI). Dalam Sekretariat Jendral DPD RI terdapat pelayanan internal, baik pelayanan pegawai dan juga pelayanan pejabat. Salah satu jenis pelayanan adalah pengaduan masalah di bidang teknologi dimana masih berbasis website. Berdasarkan hasil observasi yang dilakukan terhadap pemanfaatan sistem pelayanan pengaduan masalah berbasis web pada Seketariat Jendral DPD RI belum di gunakan secara maksimal karena keryawan dan pejabat sering melakukan aktifitas di luar ruangan atau mobile. Hal tersebut membuat sistem pengaduan masalah berjalan manual, seperti mengirim pesan menggunakan menggunakan aplikasi WhatsApp dan juga datang keruangan Bagian Pelayanan Sistem Informasi (BPSI). Melihat permasalahan yang terjadi di Sekretariat Jenderal DPD RI, maka tujuan penelitian ini adalah merancang sistem informasi layanan pengaduan masalah pegawai di seketariat jendaral dewan perwakilan daerah republik indoensia berbasis android, agar dapat memberikan layanan sesuai pengaduan dengan tepat waktu.

\section{METODOLOGI PENELITIAN}

Jenis penelitian yang dilakukan adalah penelitian kualitatif, dengan menggunakan metodologi pengembangan sistem waterfall (Gambar 1).

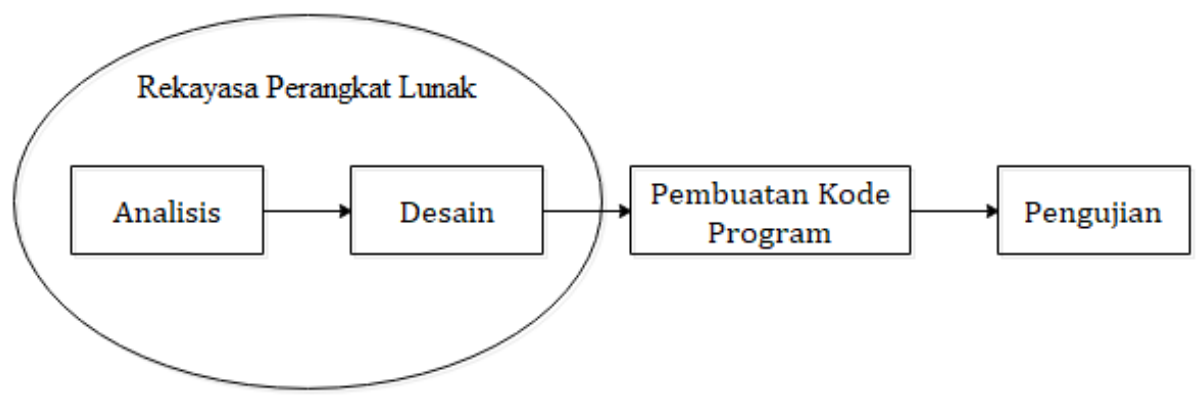

Gambar 1. Tahapan Penelitian [6]

a) Analisis

Analisis kebutuhan dilakukan untuk menspesifikasi kebutuhan software yang akan di kembangkan. Pendekatan yang dilakukan dengan cara 


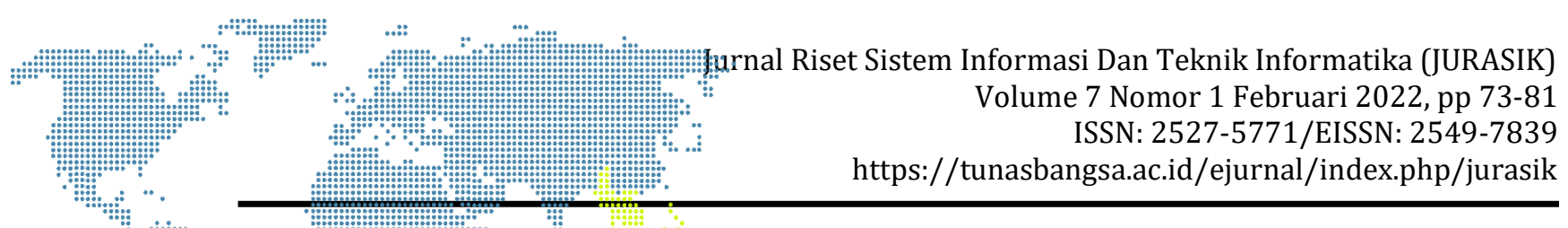

wawalneara pada 2 orang responden (pegawai BPSI) dengan masa kerja lebilh dari 2 tahun, observáas terhadap sistem yang sedang berjalan.

b) Desain "

Melakukan perancangan proses bisnis menggunakan Unified Modelling Language (UML) sebagai tahapan yang membantu menerjemahkan kebutuhan software dari hasil analisis kebutuhan.

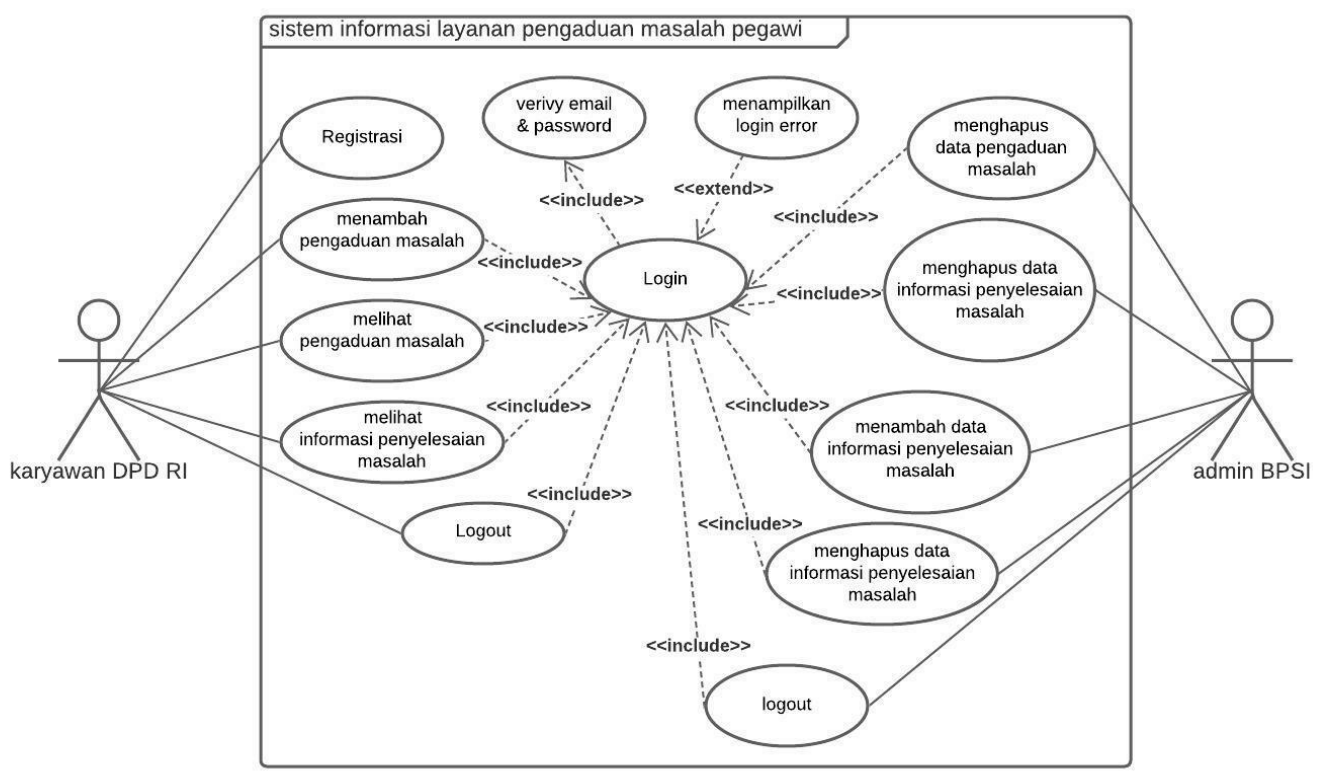

Gambar 2. Use case diagram Sistem Pengaduan Masalah

c) Pembuatan Kode Program

Perancangan sistem informasi pengaduan masalah menggunakan bahasa flutter, dan database firebase

d) Pengujian

Sistem diuji dengan metode blackbox testing. Black-box testing dipergunakan untuk menguji sistem informasi apakah masukan yang diterima dan sudah beroperasi dengan benar, dan layak digunakan.

\section{HASIL DAN PEMBAHASAN}

\subsection{Analisis Sistem Berjalan}

Berdasarkan hasil observasi dan wawancara yang dilakukan, prosedur dalam pengaduan masalah di Sekretariat Jenderal DPD RI dengan menggunakan website dimana karyawan mengajukan pengaduan masalah dalam website, lalu admin menerima pengaduan tersebut, dari admin akan meminta karyawan dari BPSI untuk menyelesaikan permasalahan tersebut.

\subsection{Analisis Kebutuhan Sistem}

Hasil observasi yang menyatakan bahwa aplikasi mobile yang dibuat harus memenuhi seluruh kebutuhan user sebagai berikut: 


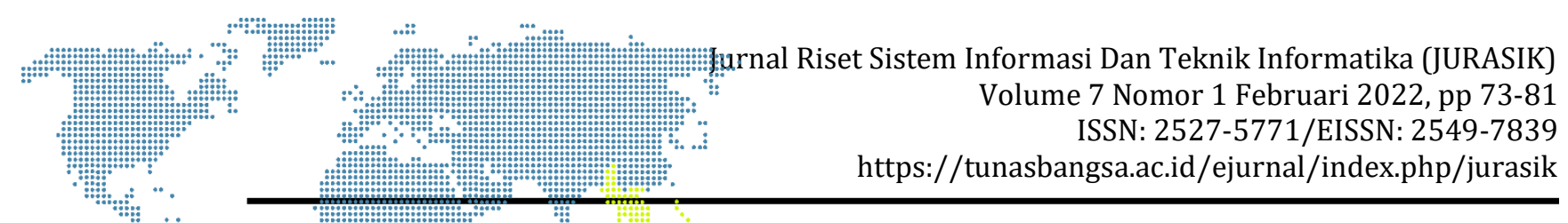

a) Aplitiosin mobile tersebut harus bisa mengirim pengaduan masalah kepada adminin:

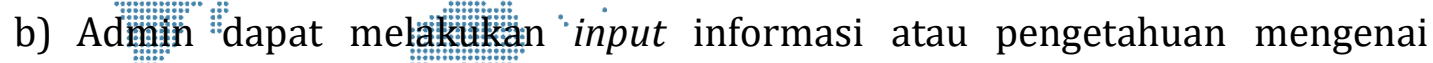
permasalahan yang sering terjadi beserta solusinya.

c) Seluruh data pengaduan masalah dan informasi dapat dilihat oleh user

d) Admin dapat menghapus data pengaduan masalah dan data informasi.

e) Pegawai dapat mengakses aplikasi dengan mudah.

\subsection{Desain Sistem}

Pada desain sistem digambarkan skema model dan proses sistem aplikasi dengan jenis diagram pada skema UML.

\subsubsection{Desain Arsitektur}

Aplikasi mobile yang akan dibuat ini menggunakan sistem arsitektur client dan server. Sistem ini akan memungkinkan pengguna untuk mengakses server secara langsung dengan bantuan API yan dimiliki Firebase. Bagian klien merupakan aplikasi yang telah dipasang pada smartphone android milik user. User dapat mendaftar akun pada aplikasi dan dapat melakukan pengaduan masalah di dalam aplikasi. Semua kegiatan yang dilakukan user dalam aplikasi termasuk bagian dari client. Bagian Server merupakan tempat penyimpanan seluruh data aplikasi yang dimasukkan oleh client dan seluruh data itu tersimpan dengan baik. Data tersebut juga dapat di akses oleh pengguna lain melalui API milik Firebase.

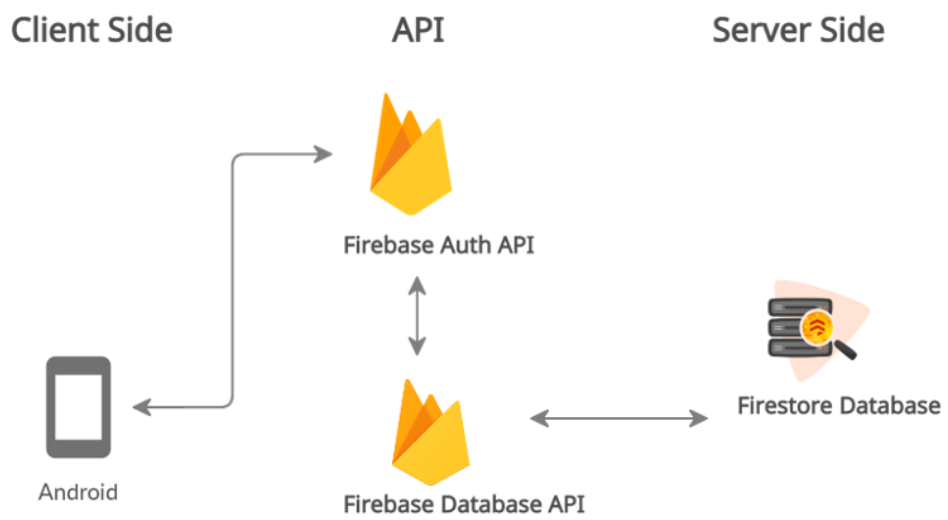

Gambar 3. Desain Arsitektur

\subsubsection{Use case diagram}

Use case diagram (Gambar 2) digunakan untuk menggambarkan aktifitas yang dapat dilakukan dalam aplikasi. Secara garis besar, kegiatan yang dapat dilakukan oleh user (pegawai DPD RI) yaitu Malukan penambahan pengaduan masalah serta meilihat data pengaduan masalah yang pernah diadukan serta dapat melihat informasi seputar permasalah teknologi. Serta kegiatan yang dapat dilakukan oleh admin (BPSI) adalah melihat pengaduan masalah menghapus pengaduan masalah serta menambah dan menghapus data informasi. 
furnal Riset Sistem Informasi Dan Teknik Informatika (JURASIK)

Volume 7 Nomor 1 Februari 2022, pp 73-81

ISSN: 2527-5771/EISSN: 2549-7839

https://tunasbangsa.ac.id/ejurnal/index.php/jurasik

\subsubsection{Use Gase Narátif}

Sistementinformasi pelayanän pengaduan masalah terdapat 2 aktor dan 7 use

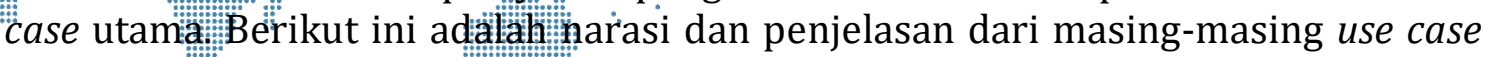
yang terdapat di Use case diagram.

Tabel 1. Use Case Naratif Register

\begin{tabular}{|l|l|l|}
\hline Nama Use Case & Register \\
\hline Aktor & Pegawai \\
\hline Deskripsi & $\begin{array}{l}\text { Proses yang dilakukan pengguna sistem untuk masuk ke dalam } \\
\text { sistem atau melakukan registration }\end{array}$ \\
\hline Pra Kondisi & Pengguna berada di halaman registration \\
\hline Tujuan & Pengguna mendaftarkan akun untuk memasuki sistem \\
\hline Skenario Normal & Aktor & Sistem \\
\hline & $\begin{array}{l}\text { Pengguna } \\
\text { mendaftarkan nama, } \\
\text { email serta password } \\
\text { pada kolom di } \\
\text { halaman register }\end{array}$ & \multicolumn{2}{|c|}{$\begin{array}{l}\text { Sistem akan menyimpan } \\
\text { data user kedalam firebase. }\end{array}$} \\
\hline & \multicolumn{2}{|c|}{} \\
\hline Skenario Alternatif & $\begin{array}{l}\text { Jika nama, email dan password atau salah satunya tidak di isi } \\
\text { maka akan muncul snackbar error. (kembali ke langkah 1) }\end{array}$ \\
\hline Pasca Kondisi & Pengguna masuk ke halaman sistem home \\
\hline
\end{tabular}

Tabel 2. Use Case Naratif Melihat Data Informasi

\begin{tabular}{|l|l|l|}
\hline Nama Use Case & Melihat data informasi \\
\hline Aktor & pegawai \\
\hline Deskripsi & Proses melihat detail informasi \\
\hline Pra Kondisi & Peawai berada di halaman home \\
\hline Tujuan & Pegawai ingin melihat data informasi \\
\hline Skenario Normal & Aktor & Sistem \\
\hline & $\begin{array}{l}\text { 1. Pegawai menekan } \\
\text { tombol informasi }\end{array}$ & $\begin{array}{l}\text { System menampilkan list } \\
\text { informasi }\end{array}$ \\
\hline & \multicolumn{1}{|c|}{$\begin{array}{l}\text { Pegawai menekan } \\
\text { salah satu list data } \\
\text { informasi }\end{array}$} & $\begin{array}{l}\text { System menampilkan detail } \\
\text { informasi }\end{array}$ \\
\hline & \multicolumn{2}{|l|}{} \\
\hline Skenario Alternatif & - & Pegawai berda di halaman detai informasi \\
\hline Pasca Kondisi & \multicolumn{2}{|l|}{} \\
\hline
\end{tabular}




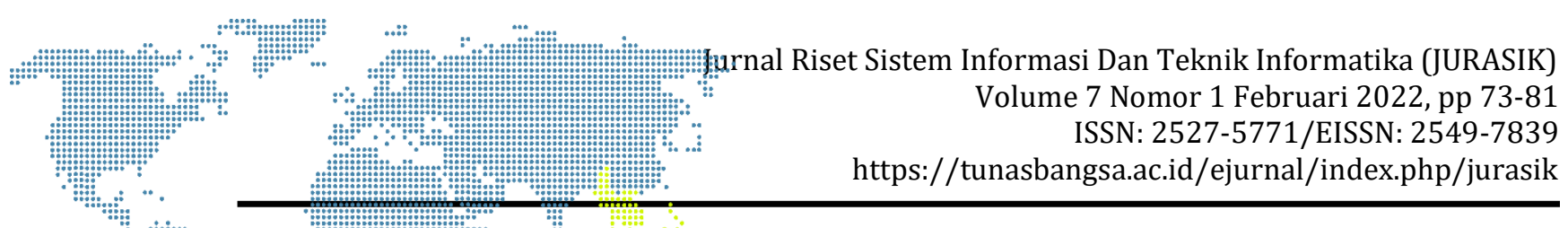

3.3.4. Classs Diagram

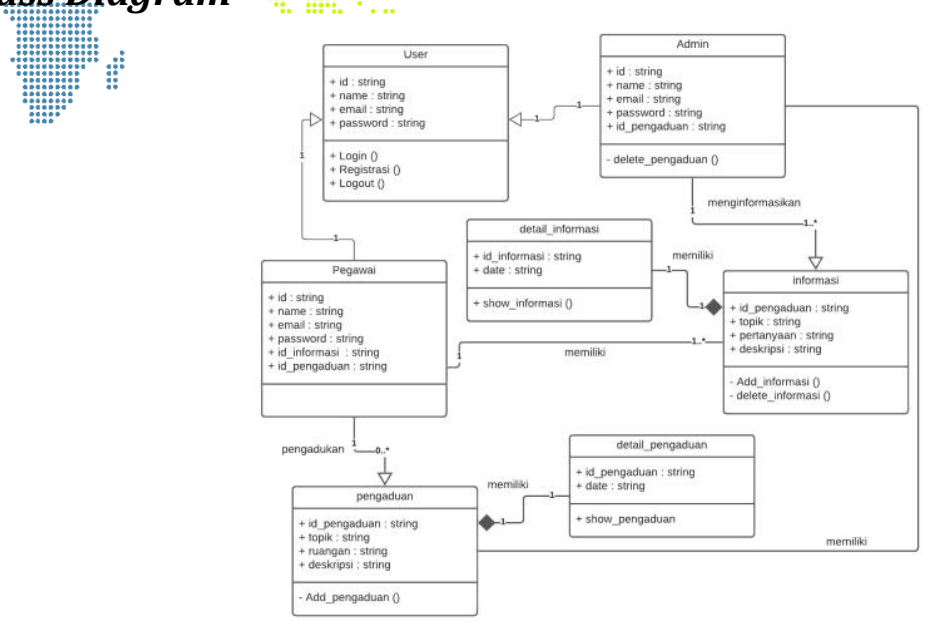

Gambar 4. Class Diagram

\subsection{Pembuatan Code Program}

Pada tahapan ini merupakan pengimplementasikan seluruh desain dan mockup kedalam kodingan dan menghasilkan tampilan antar muka serta sistem jadi. Halama splash screen (Gambar 5a) merupakan tampilan awal aplikasi yang menampilkan informasi singkat aplikasi. Halaman home (Gambar 6a) merupakan halaman utama pada pegawai dimana semua awal kegiatan dimulai. Di halaman ini pegawai dapat melihat detai akun dalam drawer, pegawai dapat mengadukan masalah dengan cara meng-klik icon pengaduan masalah. Pegawai dapat juga melihat riwayat pengaduan dengan memilih menu riwayat pengaduan dan user dapat melihat informasi.

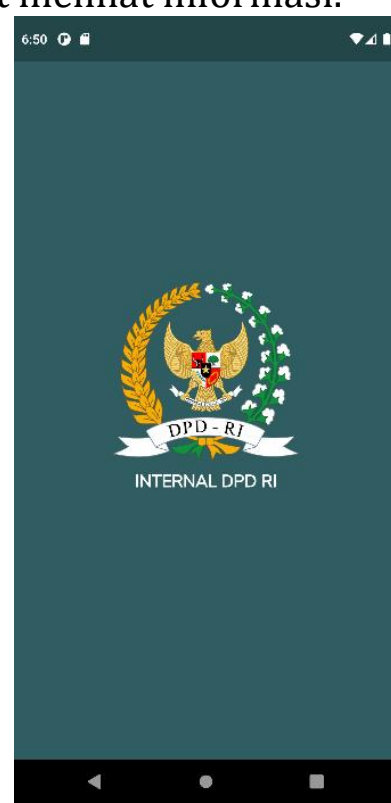

(a)
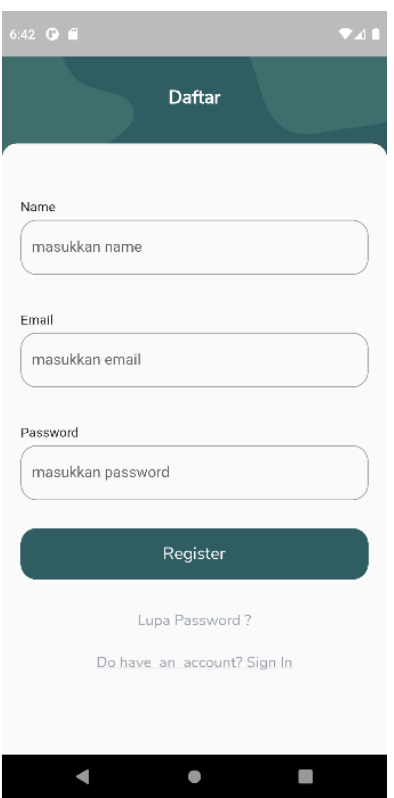

(b)
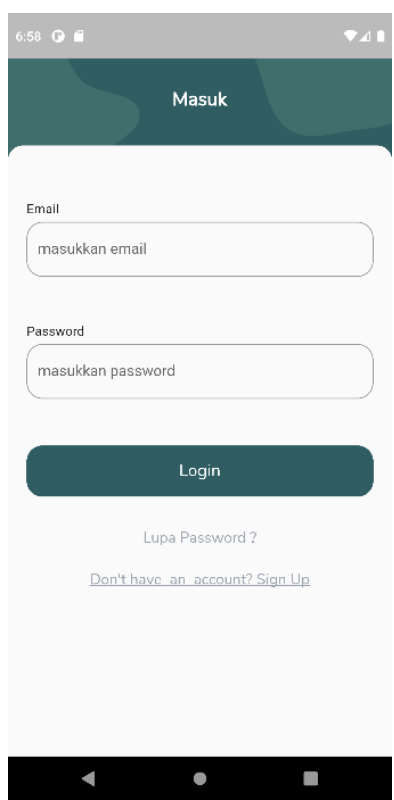

(c)

Gambar 5. (a) Splash Screen, (b) Halaman Registrasi Akun, (c) Halaman Login 


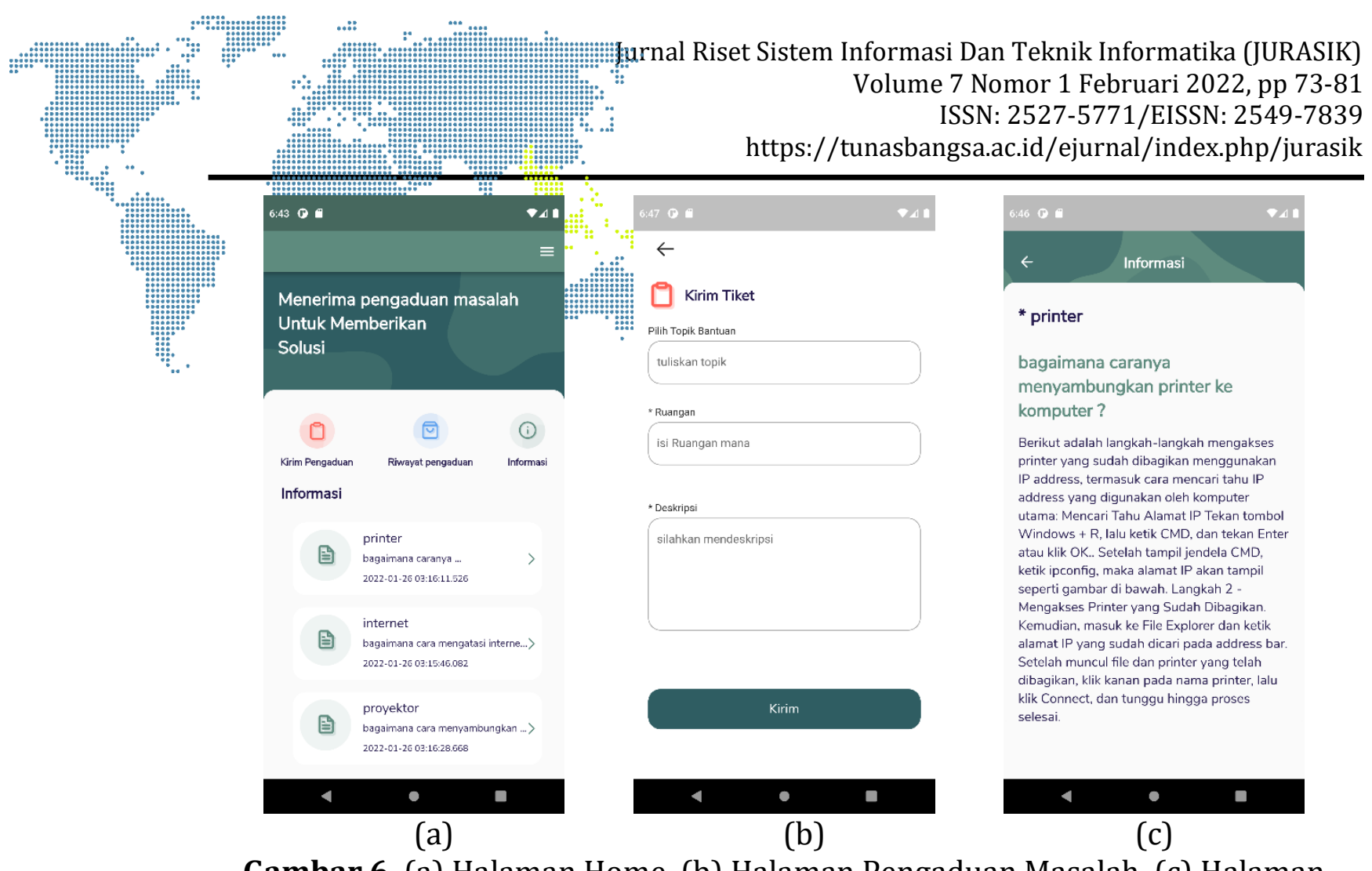

Gambar 6. (a) Halaman Home, (b) Halaman Pengaduan Masalah, (c) Halaman Detail Informasi

Pada halaman pengaduan masalah pegawai ataupun pejabat mengisi topik permasalahan, tempat permasalahan, dan menjelaskan detail masalah tersebut. Setiap pegawai yang melaporkan permasalahan bidang teknologi, akan di tampilkan pada halaman informasi (Gambar 6c) yang di tambahkan oleh admin. Kegunaan informasi ini dapat mengurangi permasalahan yang sama, karena informasi ini berisi informasi masalah beserta penyelesaiannya.

\subsection{Tahap Pengujian}

Tahap pengujian ini dilakukan untuk memastikan sistem pengaduan masalah pegawai dapat berjalan dengan semestinya. Adapun pengujian dilakukan dengan metode black-box yang bertujuan untuk fokus pada pengujian sistem.

\subsubsection{Skenario Pengujian}

Skenario pengujian terbagi menjadi dua bagian yaitu pengujian pada admin dan pengujian pada user atau pegawai. Adapun jenis-jenis skenarionya sebagai berikut:

Tabel 3. Pengujian Menu User

\begin{tabular}{|l|l|c|}
\hline \multicolumn{1}{|c|}{ Skenario Pengujian } & \multicolumn{1}{|c|}{ Deskripsi Pengujian } & Metode \\
\hline Login & Skenario login untuk memasuki sistem & Black box \\
\hline Registrasi & $\begin{array}{l}\text { Skenario registrasi untuk akun untuk dapat } \\
\text { login }\end{array}$ & Black box \\
\hline Lupa password & $\begin{array}{l}\text { Skenario meresset password dengan } \\
\text { menggunakan email }\end{array}$ & Black box \\
\hline $\begin{array}{l}\text { Tambah data } \\
\text { pengaduan masalah }\end{array}$ & $\begin{array}{l}\text { Skenario menambah data pengaduan } \\
\text { masalah }\end{array}$ & Black box \\
\hline $\begin{array}{l}\text { Menampilkan data } \\
\text { informasi }\end{array}$ & $\begin{array}{l}\text { Skenario menampilkan data informasi dari } \\
\text { admin }\end{array}$ & Black box \\
\hline
\end{tabular}




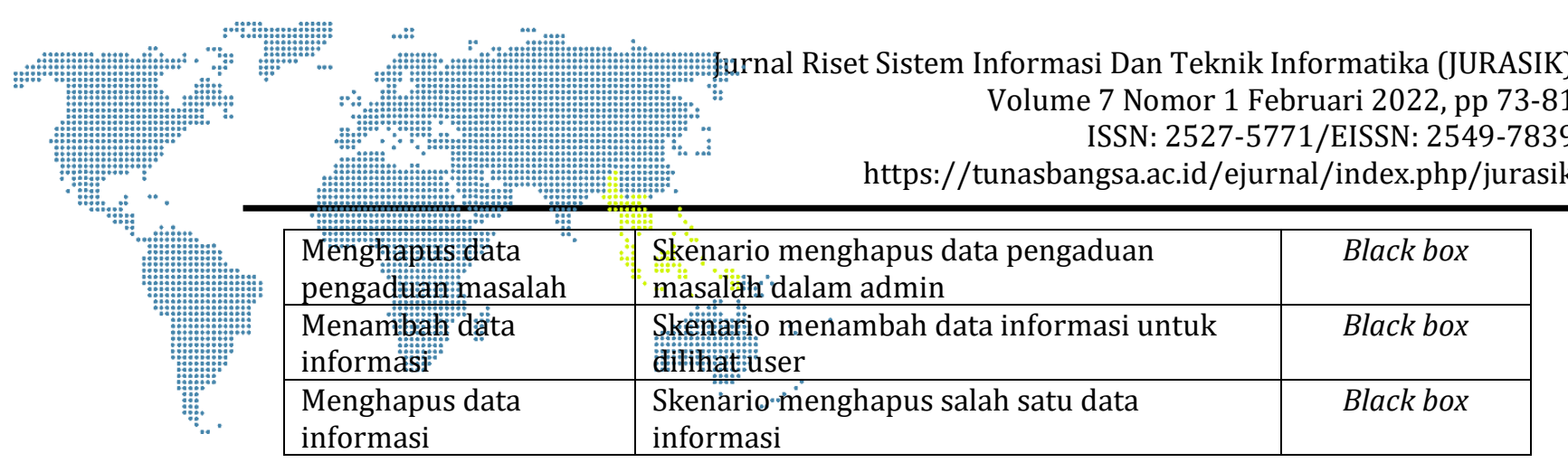

Tabel 4. Pengujian Menu Admin

\begin{tabular}{|l|l|c|}
\hline \multicolumn{1}{|c|}{ Skenario Pengujian } & \multicolumn{1}{|c|}{ Deskripsi Pengujian } & Metode \\
\hline Login & Skenario login untuk memasuki sistem & Black box \\
\hline $\begin{array}{l}\text { Menghapus data } \\
\text { pengaduan masalah }\end{array}$ & $\begin{array}{l}\text { Skenario menghapus data pengaduan masalah } \\
\text { dalam admin }\end{array}$ & Black box \\
\hline $\begin{array}{l}\text { Menambah data } \\
\text { informasi }\end{array}$ & $\begin{array}{l}\text { Skenario menambah data informasi untuk } \\
\text { dilihat user }\end{array}$ & Black box \\
\hline $\begin{array}{l}\text { Menghapus data } \\
\text { informasi }\end{array}$ & Skenario menghapus salah satu data informasi & Black box \\
\hline
\end{tabular}

\subsubsection{Hasil Pengujian}

Berikut ini adalah hasil pengujian pada sistem yang telah dilakukan. Adapun metode yang digunakan adalah dengan metode black-box.

Tabel 5. Pengujian Registrasi User

\begin{tabular}{|l|l|l|c|}
\hline \multicolumn{5}{|c|}{ Kasus dan Hasil Pengujian (Benar) } \\
\hline Skenario Uji & \multicolumn{1}{|c|}{ Hal yang Diharapkan } & \multicolumn{1}{c|}{ Hasil Uji } & Kesimpulan \\
\hline Registrasi & $\begin{array}{l}\text { Menampilkan halaman } \\
\text { utama home }\end{array}$ & $\begin{array}{l}\text { Menampilkan } \\
\text { halaman home user }\end{array}$ & Berhasil \\
\hline \multicolumn{4}{|c|}{ Kasus dan Hasil Pengujian (Salah) } \\
\hline Skenario Uji & Hal yang Diharapkan & Hasil Uji & Kesimpulan \\
\hline $\begin{array}{l}\text { Email, password } \\
\text { dan nama tidak diisi } \\
\text { dalam form }\end{array}$ & Menampilkan pesan error & $\begin{array}{l}\text { Menampilkan } \\
\text { pesan } \text { error }\end{array}$ & Berhasil \\
\hline
\end{tabular}

Tabel 6. Pengujian Menambah Pengaduan Masalah

\begin{tabular}{|l|l|l|c|}
\hline \multicolumn{5}{|c|}{ Kasus dan Hasil Pengujian (Benar) } \\
\hline Skenario Uji & \multicolumn{1}{|c|}{ Hal yang Diharapkan } \\
\hline $\begin{array}{l}\text { Menambah data } \\
\text { pengaduan masalah }\end{array}$ & $\begin{array}{l}\text { Akan berpindah ke } \\
\text { halaman home }\end{array}$ & $\begin{array}{l}\text { Menampilkan } \\
\text { halaman home user }\end{array}$ & Berhasil \\
\hline \multicolumn{4}{|c|}{ Kasus dan Hasil Pengujian (Salah) } \\
\hline Skenario Uji & Hal yang Diharapkan & Hasil Uji & Kesimpulan \\
\hline $\begin{array}{l}\text { Data yang } \\
\text { dimasukkan tidak } \\
\text { lengkap }\end{array}$ & Menampilkan pesan error & $\begin{array}{l}\text { Menampilkan } \\
\text { pesan } \text { error }\end{array}$ & Berhasil \\
\hline
\end{tabular}

Tabel 7. Pengujian Melihat Data Informasi

\begin{tabular}{|l|l|l|c|}
\hline \multicolumn{4}{|c|}{ Kasus dan Hasil Pengujian (Benar) } \\
\hline Skenario Uji & \multicolumn{1}{c|}{ Has yang Diharapkan } & Kesimpulan \\
\hline $\begin{array}{l}\text { melihat data } \\
\text { informasi }\end{array}$ & $\begin{array}{l}\text { Menampilkan data } \\
\text { informasi }\end{array}$ & $\begin{array}{l}\text { Menampilkan data } \\
\text { informasi yang } \\
\text { telah admin }\end{array}$ & Berhasil \\
\hline
\end{tabular}




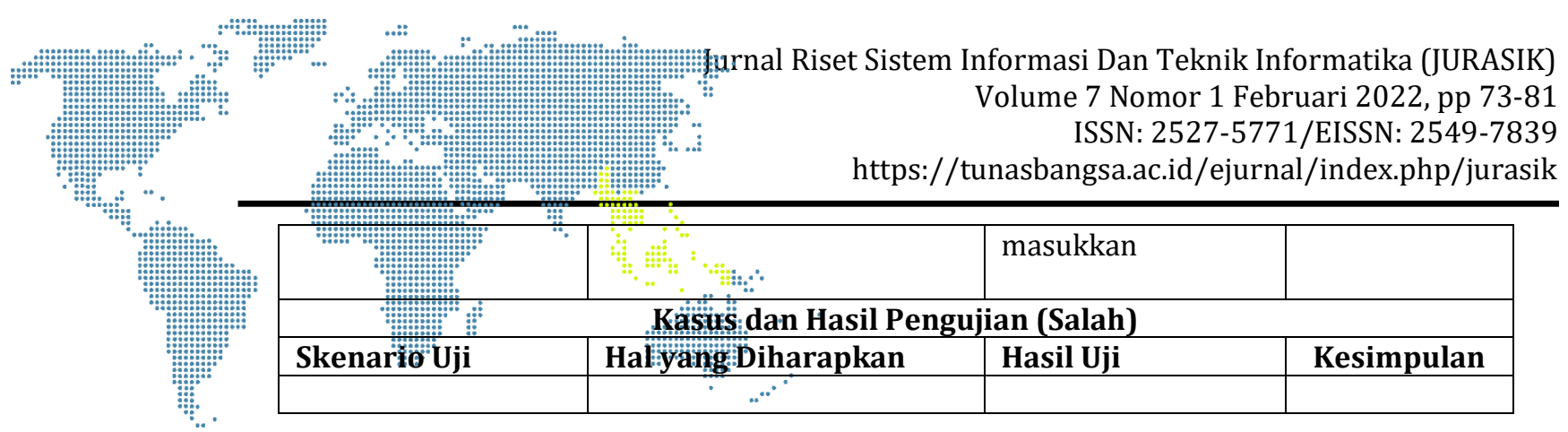

Tabel 8. Pengujian Logi Admin

\begin{tabular}{|l|l|l|c|}
\hline \multicolumn{5}{|c|}{ Kasus dan Hasil Pengujian (Benar) } \\
\hline Skenario Uji & \multicolumn{1}{|c|}{ Hal yang Diharapkan } \\
& $\begin{array}{l}\text { Menampilkan halaman } \\
\text { Admin }\end{array}$ & $\begin{array}{l}\text { Menampilkan } \\
\text { halaman Admin }\end{array}$ & Kesimpulan \\
\hline \multicolumn{4}{|c|}{ Kasus dan Hasil Pengujian (Salah) } \\
\hline Skenario Uji & Hal yang Diharapkan & Hasil Uji & Kesimpulan \\
\hline $\begin{array}{l}\text { Email dan password } \\
\text { yang dimasukkan } \\
\text { salah }\end{array}$ & Menampilkan pesan error & $\begin{array}{l}\text { Menampilkan } \\
\text { pesan } \text { error }\end{array}$ & Berhasil \\
\hline
\end{tabular}

\section{SIMPULAN}

Pengembangan aplikasi berbasis android menggunakan metodologi pengembangan waterfall, framework Flutter, dan Firebase menghasilkan sistem informasi pelayanan pengaduan masalah pegawai di Sekretariat Jenderal DPD RI bidang teknologi sehingga dapat mempermudah karyawan dalam mengadukan masalah dimana saja dengan efisien.

\section{DAFTAR PUSTAKA}

[1] Undang-Undang Republik Indonesia, “Undang-Undang Republik Indonesia Nomor 25 Tahun 2009 Tentang Pelayanan Publik," 2009.

[2] K. Ariansyah, "Kualitas Pelayanan Internal Direktorat Jenderal Sumber Daya Dan Perangkat Pos Dan Informatika," Bul. Pos dan Telekomun., vol. 11, no. 3, p. 209, 2015, doi: 10.17933/bpostel.2013.110303.

[3] Nofyat, A. Ibrahim, and A. Ambarita, "Sistem Informasi Pengaduan Pelanggan Air Berbasis Website Pada Pdam Kota Ternate," IJIS - Indones. J. Inf. Syst., vol. 3, no. 1, 2018, doi: 10.36549/ijis.v3i1.37.

[4] M. Q. Resli, "Perancangan Sistem Informasi Pusat Pelayanan Pengaduan Masyarakat (P3M) Pada Dinas Komunikasi, Informatika, Statistik dan Persandian Kabupaten Kuantan Singingi," J. Perencanaan, Sains, Teknol. dan Komput., vol. 4, no. 1, pp. 872878, 2021.

[5] Y. Firmansyah, R. Maulana, and N. Fatin, "Sistem Informasi Pengaduan Warga Berbasis Website ( Studi Kasus : Kelurahan Siantan Tengah , Pontianak Utara )," J. Cendikia, vol. XIX, no. April, pp. 397-404, 2020, [Online]. Available: https://jurnal.dcc.ac.id/index.php/JC/article/view/328.

[6] A. . Rosa and M. Shalahudin, Rekayasa Perangkat Lunak: Terstruktur dan Berorientasi Objek, Edisi Revisi. Informatika, 2019. 